\title{
Synthesis and Biological Evaluation of Novel 5,7-Dichloro-1,3-benzoxazole Derivatives
}

\author{
N. D. Jayanna, ${ }^{1}$ H. M. Vagdevi, ${ }^{1}$ J. C. Dharshan, ${ }^{2}$ T. R. Prashith Kekuda, ${ }^{3}$ \\ B. C. Hanumanthappa, ${ }^{2}$ and B. C. Gowdarshivannanavar ${ }^{2}$ \\ ${ }^{1}$ Department of Chemistry, Sahyadri Science College (Autonomous), Shimoga 577 203, India \\ ${ }^{2}$ Department of PG Studies and Research in Industrial Chemistry, Sir M. V. Government Science College, \\ Bommanakatte, Bhadravathi 577451, India \\ ${ }^{3}$ Department of Microbiology, Sahyadri Science College (Autonomous), Shimoga 577 203, India
}

Correspondence should be addressed to H. M. Vagdevi; vagdevihm@gmail.com

Received 20 June 2012; Revised 29 August 2012; Accepted 8 October 2012

Academic Editor: Mehmet Emin Duru

Copyright (C) 2013 N. D. Jayanna et al. This is an open access article distributed under the Creative Commons Attribution License, which permits unrestricted use, distribution, and reproduction in any medium, provided the original work is properly cited.

A new class of 5,7-dichloro-1,3-benzoxazole derivatives 4-11 were synthesized by fusing 5,7-dichloro-2-hydrazino-1,3benzoxazole 3 nucleus with aliphatic acids, active methylene compounds, and with selected esters to form heterocyclic ring systems like 1,2,4-triazoles, pyrazoles, and triazine moieties. The compound $\mathbf{3}$ on diazotization reaction affords the tetrazole compound. The synthesized compounds were characterized by ${ }^{1} \mathrm{H}$ NMR, IR, Mass, and ${ }^{13} \mathrm{C}$ NMR spectral data and screened for cytotoxic, antimicrobial, antioxidant, and antilipase activities. The compounds 4, 5, and 8 have shown significant antimicrobial activities, whereas compounds $\mathbf{6}$ and $\mathbf{8}$ have been emerged as leading cytotoxic agents. The compounds 9, 10, and 11 were found to be strong enzyme inhibitors.

\section{Introduction}

Wide-spread interest in the chemistry of benzoxazole derivatives in large number of products has attracted the researchers because of their potential applications in medicinal field. Benzoxazole derivative constitutes an important class of heterocyclic compounds and shows various types of biological properties such as antiviral, antineoplastic, anti-HIV-1, antitubercular, anthelmintic, antimicrobial, and antifungal activities [1, 2]. In the last few years, 2-substituted benzoxazole derivatives have been studied extensively for their biological importance.

The thiadiazole-containing 1,2,4-triazolo[3,4-b][1,3,4] thiadiazoles were seldom reported with biological activity. The chemistry of triazoles and their derivatives has always been highlighted in study of lead compound discovery study of their variety of biological activities including antifungal, antibacterial, antitubercular, anticancer, and analgesic activities [3-10]. In support for our study, pyrazoles are also an interesting group of compounds, many of which possess broad spectrum of pharmacological properties. The synthetic analogues of pyrazoles have been known to exhibit industrial, agricultural, and biological applications [11-18]. In the present work, our group is focused on synthesis of dichlorobenzoxazole derivatives to form various fused heterocyclic ring systems like 1,2,4-triazoles, pyrazoles, tetrazole and triazine moieties with benzoxazole nucleus and screened for some selected biological activities.

\section{Experimental Section}

2.1. Chemistry. Melting points were recorded on electrothermal melting point apparatus and are uncorrected. ${ }^{1} \mathrm{H}$ NMR and ${ }^{13} \mathrm{C}$ NMR spectra were recorded on Bruker $400 \mathrm{MHz}$ spectrometer in Indian Institute of Science, Bangalore, Karnataka, India. The chemical shifts are shown in $\delta$ values (ppm) with tetramethylsilane (TMS) as an internal standard. LC-MS were obtained using C 18 column on Shimadzu, LCMS 2010A, Japan. The Fourier Transform Infrared (FT-IR) spectra of the compounds were taken in $\mathrm{KBr}$ pellet $(100 \mathrm{mg})$ 
TABLE 1: Physical data of compounds 4-11.

\begin{tabular}{lcccc}
\hline Compound & $\begin{array}{c}\text { Molecular } \\
\text { formula }\end{array}$ & $\begin{array}{c}\text { Molecular } \\
\text { weight }\end{array}$ & M.P. $\left({ }^{\circ} \mathrm{C}\right)$ & Yield (\%) \\
\hline $\mathbf{4}$ & $\mathrm{C}_{8} \mathrm{H}_{3} \mathrm{Cl}_{2} \mathrm{~N}_{3} \mathrm{O}$ & 228.04 & $190-192$ & 93 \\
$\mathbf{5}$ & $\mathrm{C}_{9} \mathrm{H}_{5} \mathrm{Cl}_{2} \mathrm{~N}_{3} \mathrm{O}$ & 242.06 & $218-219$ & 95 \\
$\mathbf{6}$ & $\mathrm{C}_{7} \mathrm{H}_{2} \mathrm{Cl}_{2} \mathrm{~N}_{4} \mathrm{O}$ & 229.02 & $68-69$ & 87 \\
$\mathbf{7}$ & $\mathrm{C}_{11} \mathrm{H}_{7} \mathrm{Cl}_{2} \mathrm{~N}_{3} \mathrm{O}_{2}$ & 284.09 & $135-138$ & 89 \\
$\mathbf{8}$ & $\mathrm{C}_{10} \mathrm{H}_{6} \mathrm{Cl}_{2} \mathrm{~N}_{4} \mathrm{O}_{2}$ & 285.08 & $162-165$ & 79 \\
$\mathbf{9}$ & $\mathrm{C}_{12} \mathrm{H}_{9} \mathrm{Cl}_{2} \mathrm{~N}_{3} \mathrm{O}$ & 282.10 & $130-132$ & 90 \\
$\mathbf{1 0}$ & $\mathrm{C}_{8} \mathrm{H}_{3} \mathrm{Cl}_{2} \mathrm{~N}_{3} \mathrm{O}_{2}$ & 244.03 & $185-187$ & 85 \\
$\mathbf{1 1}$ & $\mathrm{C}_{9} \mathrm{H}_{3} \mathrm{Cl}_{2} \mathrm{~N}_{3} \mathrm{O}_{3}$ & 272.04 & $160-161$ & 84 \\
\hline
\end{tabular}

using Shimadzu (FT-IR) spectrophotometer. The elemental analysis was carried out using VarioMICROV1.7.0 (Elemental Analysersysteme $\mathrm{GmbH}$ ) instrument. The column chromatography was performed using silica gel (230-400 mesh). Silica gel GF254 plates from Merck were used for TLC and spots located either by UV or dipping in potassium permanganate solution. The chemicals were purchased from Sigma-Aldrich Co. and from SD Fine Chemicals. The solvents for column chromatography were of reagent grade and were purchased from commercial source. The yields are of purified compounds and are not optimized. The yield, melting point, molecular formula, and molecular weight of the compounds were recorded in Table 1.

2.1.1. Preparation of 5,7-Dichloro-1,3-benzoxazole-2-thiol (1). Methanol $(50 \mathrm{~mL})$ and potassium hydroxide (1.1eq) were stirred for $10 \mathrm{~min}$ and followed by slow addition of carbon disulphide (1.1eq) at room temperature. To the reaction mass, 2-amino-4,6-dichlorophenol (1.eq) was added with stirring. The reaction mass was refluxed for $6 \mathrm{hr}$ on water bath. The completion of the reaction was monitored by TLC. The reaction mass was poured on to ice cold water and acidified with glacial acetic acid ( $\mathrm{pH}$ 6). The obtained solid was filtered, dried, and recrystallized using ethanol.

Yield (95\%), M.P. $198-199^{\circ} \mathrm{C}$.

2.1.2. Preparation of 5,7-Dichloro-2-(ethylthio)-1,3-benzoxazole (2). To a mixture of sodium hydroxide $(10 \mathrm{mmol})$ and compound 1 (10 mmol) in di-methyl sulphoxide $(10 \mathrm{~mL})$, ethyl iodide $(10 \mathrm{mmol})$ was added dropwise. The reaction mass was stirred about $1 \mathrm{hr}$, and the completion of the reaction was confirmed by TLC. The reaction mass was poured on to ice cold water, filtered the obtained solid, dried, and recrystallized using hexane.

Brown color solid, yield (90\%), M.P. 38-39 ${ }^{\circ}$; IR (KBr) $\mathrm{cm}^{-1}$ : 2974 (CH alkyl), $1608(\mathrm{C}=\mathrm{N}), 1491(\mathrm{C}=\mathrm{C}), 756(\mathrm{C}-\mathrm{Cl})$; ${ }^{1} \mathrm{H} \mathrm{NMR}\left(\mathrm{CHCl}_{3}\right)$ ppm: $\delta 1.4\left(\mathrm{t}, 3 \mathrm{H}, \mathrm{CH}_{3}\right), \delta 3.26(\mathrm{q}, 2 \mathrm{H}$, $\left.\mathrm{CH}_{2}\right), \delta 7.1(\mathrm{~s}, 1 \mathrm{H}, \mathrm{Ar}), \delta 7.4(\mathrm{~s}, 1 \mathrm{H}, \mathrm{Ar} \mathrm{H}) ;{ }^{13} \mathrm{C} \mathrm{NMR}$ $\left(\mathrm{CHCl}_{3}\right): \delta 13.22\left(\mathrm{CH}_{3}\right), 14.29\left(\mathrm{CH}_{2}\right), 108.2,116.5,122.4$, 128.3, 129.62, 140.7, 153.2; MS: $\left(\mathrm{M}^{+}\right) \mathrm{m} / z 248, \mathrm{~m} / z^{+2} 250$, $m / z^{+4} 252$; Anal.Calcd for $\mathrm{C}_{9} \mathrm{H}_{7} \mathrm{Cl}_{2} \mathrm{NOS}$ (248.1): C 43.56, $\mathrm{H}$ 2.84, N 5.64; found: C 43.55, H 2.82, N 5.62.
2.1.3. Preparation of 5,7-Dichloro-2-hydrazino-1,3-benzoxazole (3). The compound 3 (10 $\mathrm{mmol})$ was taken in a roundbottomed flask and treated with hydrazine hydrate $(15 \mathrm{mmol})$ in ethanol $(15 \mathrm{~mL})$ and refluxed for $3 \mathrm{hr}$. The reaction mixture was cooled and filtered. The obtained solid was recrystallized from ethanol.

Brown color, pluffy solid, yield (70\%), M.P. 220-222 ${ }^{\circ}$; IR $(\mathrm{KBr}) \mathrm{cm}^{-1}$ : $3349\left(\mathrm{NH}_{2}\right), 3283(\mathrm{NH}), 1617(\mathrm{C}=\mathrm{N}), 1453$ $(\mathrm{C}=\mathrm{C}), 771(\mathrm{C}-\mathrm{Cl}) ;{ }^{1} \mathrm{H}$ NMR (DMSO-d6) ppm: $\delta 4.6(\mathrm{~s}, 2 \mathrm{H}$, $\mathrm{NH}_{2} \mathrm{D}_{2} \mathrm{O}$ exchangeable), $\delta 7.18(\mathrm{~s}, 1 \mathrm{H}$, Ar $\mathrm{H}), \delta 7.29(\mathrm{~s}$, $1 \mathrm{H}, \mathrm{Ar} \mathrm{H}), \delta 9.3$ (s, 1H, NH D $\mathrm{O}$ exchangeable); ${ }^{13} \mathrm{C} \mathrm{NMR}$ (DMSO-d6): $\delta 108.9,116.4,123.4,130.09,130.66,139.2$, 153.8; MS: $\left(\mathrm{M}^{+}\right) \mathrm{m} / z 218, m / z^{+2} 220, m / z^{+4} 222$; Anal.Calcd for $\mathrm{C}_{7} \mathrm{H}_{5} \mathrm{Cl}_{2} \mathrm{~N}_{3} \mathrm{O}$ (218.04): C 38.56, $\mathrm{H}$ 2.31, $\mathrm{N}$ 19.27; found: C 38.53, H 2.30, N 19.25.

\subsubsection{Preparation of 6,8-Dichloro[1,2,4]triazolo[3,4-b][1,3]} benzoxazole (4). The mixture of compound $3(10 \mathrm{mmol})$, formic acid $(10 \mathrm{~mL})$, and catalytic amount of concentrated hydrochloric acid was heated under reflux for $5 \mathrm{hr}$. The reaction mixture was allowed to cool to room temperature and poured onto water $(50 \mathrm{~mL})$. The obtained solid was filtered, washed with ethanol, dried, and recrystallized using methanol.

Half white solid; IR $(\mathrm{KBr}) \mathrm{cm}^{-1}: 1627(\mathrm{C}=\mathrm{N}), 1459$ $(\mathrm{C}=\mathrm{C}), 748(\mathrm{C}-\mathrm{Cl}) ;{ }^{1} \mathrm{H}$ NMR (DMSO-d6) ppm: $\delta 7.17(\mathrm{~s}, 1 \mathrm{H}$, Ar H), $\delta 7.35$ (s, 1H, Ar H), $\delta 12.18(\mathrm{~s}, 1 \mathrm{H},=\mathrm{CH}) ;{ }^{13} \mathrm{C} \mathrm{NMR}$ (DMSO-d6): $\delta 111.2,115.5,117.3,122.9,130.2,132.23,141.9$, 155.9; MS: $\left(\mathrm{M}^{+}\right) \mathrm{m} / z 228, m / z^{+2} 230, m / z^{+4} 232$; Anal.Calcd for $\mathrm{C}_{8} \mathrm{H}_{3} \mathrm{Cl}_{2} \mathrm{~N}_{3} \mathrm{O}$ (228.04): C 42.14, $\mathrm{H}$ 1.33, $\mathrm{N}$ 18.43; found: C 42.11, H 1.30, N 18.42.

\subsubsection{Preparation of 6,8-Dichloro-3-methyl[1,2,4]triazolo} $[3,4-b][1,3]$ benzoxazole (5). The compound 3 (10 mmol) was dissolved in glacial acetic acid $(20 \mathrm{~mL})$ and stirred under reflux for $10 \mathrm{hr}$. The reaction mixture was allowed to cool to room temperature and poured onto water $(50 \mathrm{~mL})$. The solid thus formed was collected by filtration. The crude solid was washed with ethanol $(20 \mathrm{~mL})$, dried, and recrystallized from methanol.

Buff color solid; IR (KBr) cm $\mathrm{cm}^{-1}: 2990\left(\mathrm{CH}_{3}\right), 1630(\mathrm{C}=\mathrm{N})$, $1465(\mathrm{C}=\mathrm{C}), 773(\mathrm{C}-\mathrm{Cl}) ;{ }^{1} \mathrm{H}$ NMR (DMSO-d6) ppm: $\delta 1.9(\mathrm{~s}$, $\left.1 \mathrm{H}, \mathrm{CH}_{3}\right), \delta 7.3(\mathrm{~s}, 1 \mathrm{H}, \mathrm{Ar} \mathrm{H}), \delta 7.4(\mathrm{~s}, 1 \mathrm{H}, \mathrm{Ar} \mathrm{H}) ;{ }^{13} \mathrm{C} \mathrm{NMR}$ (DMSO-d6): $\delta 29.79\left(\mathrm{CH}_{3}\right), 116.15,117.4,124.82,130.9$, 132.5, 143.04, 145.21, 158.71; MS: $\left(\mathrm{M}^{+}\right) \mathrm{m} / z 242, \mathrm{~m} / z^{+2} 244$, $m / z^{+4}$ 246; Anal.Calcd for $\mathrm{C}_{9} \mathrm{H}_{5} \mathrm{Cl}_{2} \mathrm{~N}_{3} \mathrm{O}$ (242.06): C 44.66, $\mathrm{H}$ 2.08, N 17.39; found: C 44.62, H 2.06, N 17.41.

2.1.6. Preparation of 5,7-Dichlorotetrazolo[5,1-b][1,3]benzoxazole (6). A solution of sodium nitrite $(1.04 \mathrm{~g}, 15 \mathrm{mmol})$ in $10 \mathrm{~mL}$ of water was added dropwise to an ice cold solution of compound $3(10 \mathrm{mmol})$ in acetic acid $(10 \mathrm{~mL})$. The reaction mixture was kept for stirring about an hour on ice bath at $-5^{\circ} \mathrm{C}$. The reaction mixture was allowed to stand for overnight at room temperature. Then, it was poured onto water $(100 \mathrm{~mL})$. The solid precipitated was filtered off and crystallized from methanol. 
Light yellow color solid; IR $(\mathrm{KBr}) \mathrm{cm}^{-1}: 164 \mathrm{O}(\mathrm{C}=\mathrm{N})$, $1450(\mathrm{C}=\mathrm{C}), 740(\mathrm{C}-\mathrm{Cl}) ;{ }^{1} \mathrm{H}$ NMR $\left(\mathrm{CHCl}_{3}\right) \mathrm{ppm}: \delta 7.2(\mathrm{~s}$, $1 \mathrm{H}, \operatorname{Ar~H}), \delta 7.39$ (s, $1 \mathrm{H}, \mathrm{Ar} \mathrm{H}) ;{ }^{13} \mathrm{C} \mathrm{NMR}\left(\mathrm{CHCl}_{3}\right): \delta 115.32$, 116.9, 125.12, 130.2, 141.41, 145.4, 156.34; MS: $\left(\mathrm{M}^{+}\right) \mathrm{m} / z 229$, $m / z^{+2} 231, m / z^{+4} 233$; Anal.Calcd for $\mathrm{C}_{7} \mathrm{H}_{2} \mathrm{Cl}_{2} \mathrm{~N}_{4} \mathrm{O}$ (229.02): C 36.71, H 0.88, N, 24.46; found: C 36.69, H 0.83, N 24.42.

2.1.7. Preparation of 2-(5,7-Dichloro-1,3-benzoxazol-2-yl)-5methyl-2,4-dihydro-3H-pyrazol-3-one (7). The compound 3 $(10 \mathrm{mmol})$ and ethyl acetoacetate $(0,7 \mathrm{~g}, 10 \mathrm{mmol})$ mixture was stirred under reflux in absolute ethanol $(30 \mathrm{~mL})$ for $8 \mathrm{hr}$. The reaction mixture was allowed to cool to room temperature, poured onto cold water $(50 \mathrm{~mL})$. The precipitate was filtered off, dried, and crystallized from methanol.

Light brown color solid; IR (KBr) cm ${ }^{-1}: 2998$ (alkyl), 1720 $(-\mathrm{C}=\mathrm{O}), 1630(\mathrm{C}=\mathrm{N}), 1453(\mathrm{C}=\mathrm{C}), 726(\mathrm{C}-\mathrm{Cl}) ;{ }^{1} \mathrm{H}$ NMR (DMSO-d6) ppm: $\delta 3.3$ (s, 2H, $\mathrm{CH}_{2}$ ), $\delta 3.37\left(\mathrm{~s}, 3 \mathrm{H}, \mathrm{CH}_{3}\right), \delta$ 7.28 (s, $1 \mathrm{H}, \mathrm{Ar} \mathrm{H}), \delta 7.4$ (s, $1 \mathrm{H}, \mathrm{Ar} \mathrm{H}) ;{ }^{13} \mathrm{C}$ NMR (DMSO-d6): $\delta 13.5\left(\mathrm{CH}_{3}\right), 28\left(\mathrm{CH}_{2}\right), 110.25,115.33,120.34,124.4,130.5$, 142.2, 144.12, 156.43, 162.24; MS: $\left(\mathrm{M}^{+}\right) \mathrm{m} / z 284, \mathrm{~m} / z^{+2} 286$, $\mathrm{m} / z^{+4}$ 288; Anal.alcd for $\mathrm{C}_{11} \mathrm{H}_{7} \mathrm{Cl}_{2} \mathrm{~N}_{3} \mathrm{O}_{2}$ (284.09): $\mathrm{C} 46.50, \mathrm{H}$ 2.48, N 14.79; found: C 46.49, H 2.46, N 14.78.

\subsubsection{Preparation of 5-Amino-2-(5,7-dichloro-1,3-benzoxa-} zol-2-yl)-2,4-dihydro-3H-pyrazol-3-one (8). To a freshly prepared warmed ethanolic sodium ethoxide solution, compound $3(10 \mathrm{mmol})$ and ethyl cyanoacetate $(1.3 \mathrm{~g}, 10 \mathrm{mmol})$ mixture was added. The mixture was stirred under reflux for $8 \mathrm{hr}$. The reaction mixture was allowed to cool to room temperature, then poured onto cold water and neutralized with acetic acid. The solid product was filtered off, washed with water, ethanol, dried, and crystallized from methanol.

Light brown color solid; IR $(\mathrm{KBr}) \mathrm{cm}^{-1}: 3295\left(-\mathrm{NH}_{2}\right)$, $1730(\mathrm{C}=\mathrm{O}), 1637(\mathrm{C}=\mathrm{N}), 1444(\mathrm{C}=\mathrm{C}), 778(\mathrm{C}-\mathrm{Cl}){ }^{1} \mathrm{H}$ NMR (DMSO-d6) ppm: $\delta 3.4\left(\mathrm{~s}, 2 \mathrm{H}, \mathrm{CH}_{2}\right), \delta 6.37\left(\mathrm{~s}, 2 \mathrm{H},-\mathrm{NH}_{2}\right.$ $\mathrm{D}_{2} \mathrm{O}$ exchangeable), $\delta 7.2(\mathrm{~s}, 1 \mathrm{H}, \mathrm{Ar} \mathrm{H}), \delta 7.3(\mathrm{~s}, 1 \mathrm{H}, \mathrm{Ar} \mathrm{H})$; ${ }^{13} \mathrm{C}$ NMR (DMSO-d6): $\delta 28.2\left(\mathrm{CH}_{2}\right), 111.41,114.71,121.01$, 124.5, 129.6, 142.9, 144.76, 157.15, 161.93; MS: $\left(\mathrm{M}^{+}\right) \mathrm{m} / \mathrm{z}$ 286, $\mathrm{m} / z^{+2} 288, \mathrm{~m} / \mathrm{z}^{+4} 290$; Anal.Calcd for $\mathrm{C}_{10} \mathrm{H}_{6} \mathrm{Cl}_{2} \mathrm{~N}_{4} \mathrm{O}_{2}$ (285.08): C 42.13, H 2.12, N 19.65; found: C 42.10, H 2.10, N 19.64 .

2.1.9. Preparation of 5,7-Dichloro-2-(3,5-dimethyl-1H-pyrazol-1-yl)-1,3-benzoxazole (9). The compound 3 (10 mmol) and acetyl acetone $(10 \mathrm{mmol})$ mixture in absolute ethanol $(30 \mathrm{~mL})$ was stirred under reflux for $5 \mathrm{hr}$. The reaction mixture was allowed to cool at room temperature and poured onto water. The precipitate was filtered off, dried, and crystallized from methanol.

Light brown color solid; IR (KBr) cm ${ }^{-1}: 2998$ (alkyl), 1637 $(\mathrm{C}=\mathrm{N}), 1447(\mathrm{C}=\mathrm{C}), 750(\mathrm{C}-\mathrm{Cl}) ;{ }^{1} \mathrm{H}$ NMR (DMSO-d6) ppm: $\delta 3.0\left(\mathrm{~s}, 3 \mathrm{H}, \mathrm{CH}_{3}\right), \delta 3.04\left(\mathrm{~s}, 3 \mathrm{H}, \mathrm{CH}_{3}\right), \delta 6.3(\mathrm{~s}, 1 \mathrm{H},=\mathrm{CH}), \delta$ $7.63(\mathrm{~s}, 1 \mathrm{H}, \mathrm{Ar} \mathrm{H}), \delta 7.83(\mathrm{~s}, 1 \mathrm{H}, \mathrm{Ar} \mathrm{H}) ;{ }^{13} \mathrm{C}$ NMR (DMSOd6): $\delta 13.7\left(\mathrm{CH}_{3}\right), 13.92\left(\mathrm{CH}_{3}\right), 111.1,116.32,118.17,124.8$, 130.8, 142.9, 143.83, 144.4, 154.38, 155.24; MS: $\left(\mathrm{M}^{+}\right) \mathrm{m} / z 282$, $m / z^{+2} 284, m / z^{+4} 286$; Anal.Calcd for $\mathrm{C}_{12} \mathrm{H}_{9} \mathrm{Cl}_{2} \mathrm{~N}_{3} \mathrm{O}$ (282.1): C 51.09, H 3.22, N 14.89; found: C 51.08, H 3.21, N 14.88 .

2.1.10. Preparation of 6,8-Dichloro[1,2,4]triazolo[3,4-b][1,3] benzoxazol-3(2H)-one (10). The compound 3 (10 mmol) and Ethyl chloroformate $(10 \mathrm{mmol})$ mixture in ethanol was refluxed for $3 \mathrm{hr}$. The reaction mass was cooled to room temperature and filtered the solid. The obtained solid was recrystallized using methanol.

Half white color solid; IR (KBr) $\mathrm{cm}^{-1}: 3200(\mathrm{NH}), 1725$ $(\mathrm{C}=\mathrm{O}), 1622(\mathrm{C}=\mathrm{N}), 1448(\mathrm{C}=\mathrm{C}), 779(\mathrm{C}-\mathrm{Cl}) ;{ }^{1} \mathrm{H}$ NMR (DMSO-d6) ppm: $\delta 7.2(\mathrm{~s}, 1 \mathrm{H}, \mathrm{Ar} \mathrm{H}), \delta 7.29$ (s, $1 \mathrm{H}, \mathrm{Ar} \mathrm{H}), \delta$ $8.18(\mathrm{~s}, 1 \mathrm{H},=\mathrm{NH}) ;{ }^{13} \mathrm{C}$ NMR (DMSO-d6): $\delta$ 113.81, 119.31, 123.29, 130.21, 142.2, 144.54, 155.41, 163.55; MS: $\left(\mathrm{M}^{+}\right) \mathrm{m} / \mathrm{z}$ 244, $m / z^{+2} 246, m / z^{+4} 248$; Anal.Calcd for $\mathrm{C}_{8} \mathrm{H}_{3} \mathrm{Cl}_{2} \mathrm{~N}_{3} \mathrm{O}_{2}$ (244.03): C 39.37, H 1.24, N 17.22; found: C 39.35, H 1.23, N 17.20.

\subsubsection{Preparation of 7,9-Dichloro-2H-[1,2,4]triazine[3,4-b] \\ [1,3]benzoxazole-3,4-dione (11). The compound 3} $(10 \mathrm{mmol})$ and diethyl oxalate $(10 \mathrm{mmol})$ were dissolved in ethanol $(20 \mathrm{~mL})$ and refluxed for $3 \mathrm{hr}$. The reaction mass was cooled to room temperature and filtered the solid. The obtained solid was recrystallized using methanol.

Half white color solid; IR (KBr) $\mathrm{cm}^{-1}: 3223(\mathrm{NH}), 1730$ $(\mathrm{C}=\mathrm{O}), 1620(\mathrm{C}=\mathrm{N}), 1439(\mathrm{C}=\mathrm{C}), 771(\mathrm{C}-\mathrm{Cl}) ;{ }^{1} \mathrm{H}$ NMR (DMSO-d6) ppm: $\delta 7.3$ (s, 1H, Ar H), $\delta 7.32(\mathrm{~s}, 1 \mathrm{H}, \mathrm{Ar}$ $\mathrm{H}), \delta 8.5(\mathrm{~s}, 1 \mathrm{H},=\mathrm{NH}) ;{ }^{13} \mathrm{C}$ NMR (DMSO-d6): $\delta 115.11$, 119.23, 123.43, 130.55, 142.09, 145.64, 155.92, 162.91, 163.55; MS: $\left(\mathrm{M}^{+}\right) \mathrm{m} / z$ 272, $\mathrm{m} / \mathrm{z}^{+2} 274, \mathrm{~m} / \mathrm{z}^{+4}$ 276; Anal.Calcd for $\mathrm{C}_{9} \mathrm{H}_{3} \mathrm{Cl}_{2} \mathrm{~N}_{3} \mathrm{O}_{3}$ (272.04): C 39.73, H 1.11, N 15.45; found: C 39.71, H 1.08, N 15.42.

\subsection{Biological Activities}

2.2.1. Antibacterial Activity. The antibacterial efficacy of the compounds was tested against Gram-positive bacteria, namely, Staphylococcus aureus, Bacillus cereus, and against Gram-negative bacteria, namely, Pseudomonas aeruginosa, Klebsiella pneumonia, and Escherichia coli by agar well diffusion method [19]. The $24 \mathrm{hr}$ old Muller-Hinton broth cultures of test bacteria were swabbed on sterile Muller-Hinton agar plates using sterile cotton swab followed by punching wells of $6 \mathrm{~mm}$ with the help of sterile cork borer. The standard drug (Chloramphenicol, $1 \mathrm{mg} / \mathrm{mL}$ of sterile distilled water), compounds 4-11 (20 mg/mL of 10\% DMSO), and control (10\% DMSO) were added to, respectively, labeled wells. The plates were allowed to stand for 30 minutes and incubated at $37^{\circ} \mathrm{C}$ for $24 \mathrm{hr}$ in upright position, and the zone of inhibition was recorded.

2.2.2. Minimum Inhibitory Concentration (MIC). MIC was determined by micro-dilution method using serially diluted compounds ( 0 to $20000 \mu \mathrm{g} / \mathrm{mL}$ ) in nutrient broth tubes. The standardized $0.1 \mathrm{~mL}$ of inoculum $\left(10^{7} \mathrm{CFU} / \mathrm{mL}\right)$ of test bacteria was added to each tube and incubated at $37^{\circ} \mathrm{C}$ for $24 \mathrm{hr}$. Two control tubes were maintained for each organism. The 
lowest concentration (highest dilution) of the compounds that produced no visible growth when compared with the control tubes was regarded as MIC [20].

2.2.3. Antioxidant Activity. DPPH Assay. The radical scavenging ability of synthesized compounds and the ascorbic acid (standard) was tested on the basis of radical scavenging effect on DPPH free radical. Different concentrations (25, $50,100,200$, and $400 \mu \mathrm{g} / \mathrm{mL}$ ) of compounds and standard were prepared in methanol. In clean and labeled test tubes, $2 \mathrm{~mL}$ of DPPH solution $(0.002 \%$ in methanol) was mixed with $2 \mathrm{~mL}$ of different concentrations of compounds and standard separately. The tubes were incubated at room temperature in dark for 30 minutes and the optical density was measured at $517 \mathrm{~nm}$ using UV-visible spectrophotometer. The absorbance of the DPPH control was also noted. The scavenging activity was calculated using the formula: Scavenging activity $(\%)=$ $A-B / A \times 100$, where $A$ is the absorbance of DPPH and $B$ is the absorbance of DPPH in standard combination [21].

Ferric Reducing Assay. Different concentrations (25, 50, 100,200 and $400 \mu \mathrm{g} / \mathrm{mL}$ ) of compounds and standard (tannic acid) in $1 \mathrm{~mL}$ of methanol were mixed in separate tubes with $2.5 \mathrm{~mL}$ of phosphate buffer $(200 \mathrm{mM}, \mathrm{pH} 6.6)$ and $2.5 \mathrm{~mL}$ of $1 \%$ potassium ferricyanide. The tubes were placed in water bath for 20 minutes at $50^{\circ} \mathrm{C}$, cooled rapidly, and mixed with $2.5 \mathrm{~mL}$ of $10 \%$ trichloroacetic acid and $0.5 \mathrm{~mL}$ of $0.1 \%$ ferric chloride. The amount of iron (II)-ferricyanide complex formed was determined by measuring the formation of Perl's Prussian blue at $700 \mathrm{~nm}$ after 10 minutes. The increase in absorbance of the reaction mixture indicated the increased reducing power [22].

\subsubsection{Pancreatic Lipase Inhibitory Activity.}

Extraction of Lipase from Chicken (Gallus domesticus) Pancreas. Pancreas of freshly slaughtered chicken were collected, washed, and placed in ice cold sucrose solution $(0.01 \mathrm{M})$. The pancreas was homogenized in $0.01 \mathrm{M}$ sucrose, centrifuged. The supernatant liquid was separated and subjected to ammonium sulphate precipitation ( $50 \%$ saturation). The pellet obtained after centrifugation was dissolved in sucrose solution and again saturated with 50\% ammonium sulphate and centrifuged. The pellet obtained was dissolved in phosphate buffer and used as enzyme source [23].

Determination of Chicken Pancreatic Lipase Activity. The activity of lipase was determined by incubating an emulsion containing $8 \mathrm{~mL}$ of olive oil, $0.4 \mathrm{~mL}$ of phosphate buffer, and $1 \mathrm{~mL}$ of chicken pancreatic lipase for $1 \mathrm{hr}$ in rotary shaker, followed by stopping the reaction by the addition of $1.5 \mathrm{~mL}$ of a solution containing acetone and $95 \%$ ethanol $(1: 1)$. The liberated fatty acids were determined by titrating the solution against $0.02 \mathrm{M} \mathrm{NaOH}$ (standardized by $0.01 \mathrm{M}$ oxalic acid) using phenolphthalein as an indicator [24,25].

Lipase Inhibitory Activity. Lipase inhibitory activity of different concentrations of synthesized compounds $(2.5,5$, 10 , and $20 \mathrm{mg} / \mathrm{mL}$ ) was tested by mixing $100 \mu \mathrm{L}$ of each compound, $8 \mathrm{~mL}$ of oil emulsion, and $1 \mathrm{~mL}$ of chicken pancreatic lipase followed by incubation for 60 minutes. The reaction was stopped by adding $1.5 \mathrm{~mL}$ of a solution containing acetone and 95\% ethanol (1:1). The liberated fatty acids were determined by titrating the solution against $0.02 \mathrm{M} \mathrm{NaOH}$ using phenolphthalein as an indicator [26]. The orlistat was used as standard lipase inhibitor, and the percentage inhibition of lipase activity was calculated using the formula:

Lipase inhibition $=A-B / A \times 100$, where $A$ is lipase activity, and $B$ is activity of lipase when incubated with the compounds.

2.2.5. Cytotoxic Activity. The brine shrimp lethality test was conducted to determine cytotoxic activity of compounds [27]. Brine shrimp Artemianauplii eggs (Nihon Animal Pharmaceutical Inc., Tokyo, Japan) were hatched in a container filled with air-bubbled artificial sea water, which was prepared with $10 \mathrm{gm}$ of a commercial salt mixture (GEX Inc., Osaka, Japan) and $500 \mathrm{~mL}$ of distilled water. After $36-48 \mathrm{hr}$, the phototropic shrimps were collected by pipette for bioassay. Twenty-five shrimps were transferred to each vial containing different concentrations of compounds. The artificial sea water was added to make up to $5 \mathrm{~mL}$ and incubated at $25^{\circ} \mathrm{C}$, and survived shrimps were counted microscopically in the stem of the pipette against a lightened background after $24 \mathrm{hr}$.

\section{Results and Discussion}

3.1. Chemistry. The compound 5,7-dichloro-2-(ethylthio)1,3-benzoxazole 2 was treated with hydrazine hydrate to afford 5,7-dichloro-2-hydrazino-1,3-benzoxazole 3 . The compound 3 was reported in another route [28], but it is possible to synthesize the intermediate by direct method (Scheme 1). The compound 3 was characterized by ${ }^{1} \mathrm{H}$ NMR, which exhibited two singlets at $\delta 4.6, \delta 9.3$ for $-\mathrm{NH}_{2}$ and $-\mathrm{NH}$ protons, respectively $\left(\mathrm{D}_{2} \mathrm{O}\right.$ exchangeable). The compound 3 on treatment with different reagents gives compounds 4-11 (Scheme 2).

The compound $\mathbf{3}$ on reacting with aliphatic acids like formic acid and acetic acid afforded 6,8dichloro[1,2,4] triazolo[3,4-b][1,3]benzoxazole derivative $\mathbf{4}$ and 5 , respectively. In ${ }^{1} \mathrm{H}$ NMR, the presence of $-\mathrm{CH}_{3}$ at $\delta$ 1.9 confirmed the formation of compound, $\mathbf{5}$ whereas it did not appear in compound $\mathbf{4}$. The compound $\mathbf{4}$ shows a singlet at $\delta 12.18$ for triazole proton. The compound 3 reacted with nitrous acid in presence of acetic acid yielded 5,7dichlorotetrazolo[5,1-b][1,3] benzoxazole 6 , the formation of tetrazole was confirmed by the absence of $-\mathrm{NH}$ and $-\mathrm{NH} 2$ protons and the presence of only two aromatic protons at $\delta 7.2$ and 7.39. The compound 2-(5,7-dichloro-1,3benzoxazol-2-yl)-5-methyl-2,4-dihydro-3H-pyrazol-3-one 7 was formed by the reaction between compound $\mathbf{3}$ and ethyl acetoacetate.

The ethyl cyanoacetate treated with compound 3 yields 5-amino-2-(5,7-dichloro-1,3-benzoxazol-2-yl)-2,4-dihydro$3 H$-pyrazol-3-one 8. On the other hand, 5,7-dichloro-2hydrazino-1,3-benzoxazole 3 was condensed with acetyl acetone to form 5,7-dichloro-2-(3,5-dimethyl- $1 \mathrm{H}$-pyrazol1-yl)-1,3-benzoxazole 9 in excellent yield. Two singlets 


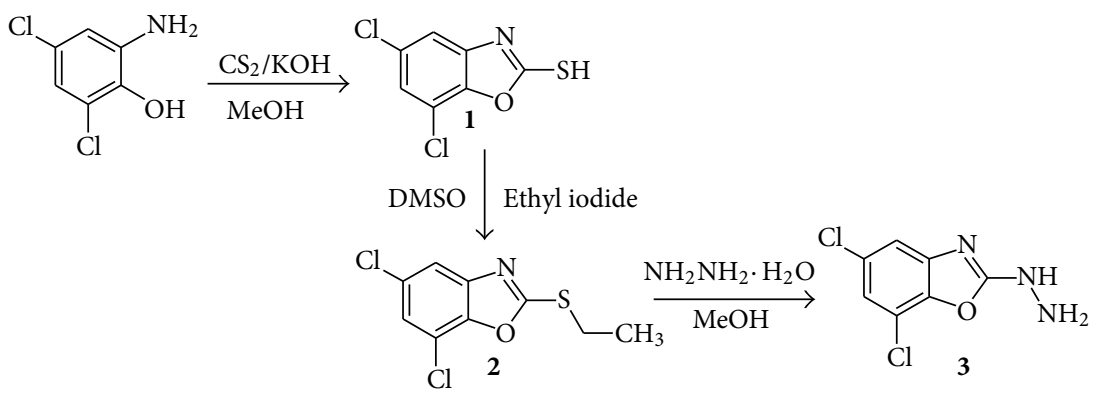

SCHEME 1: Synthetic route for compound 3.

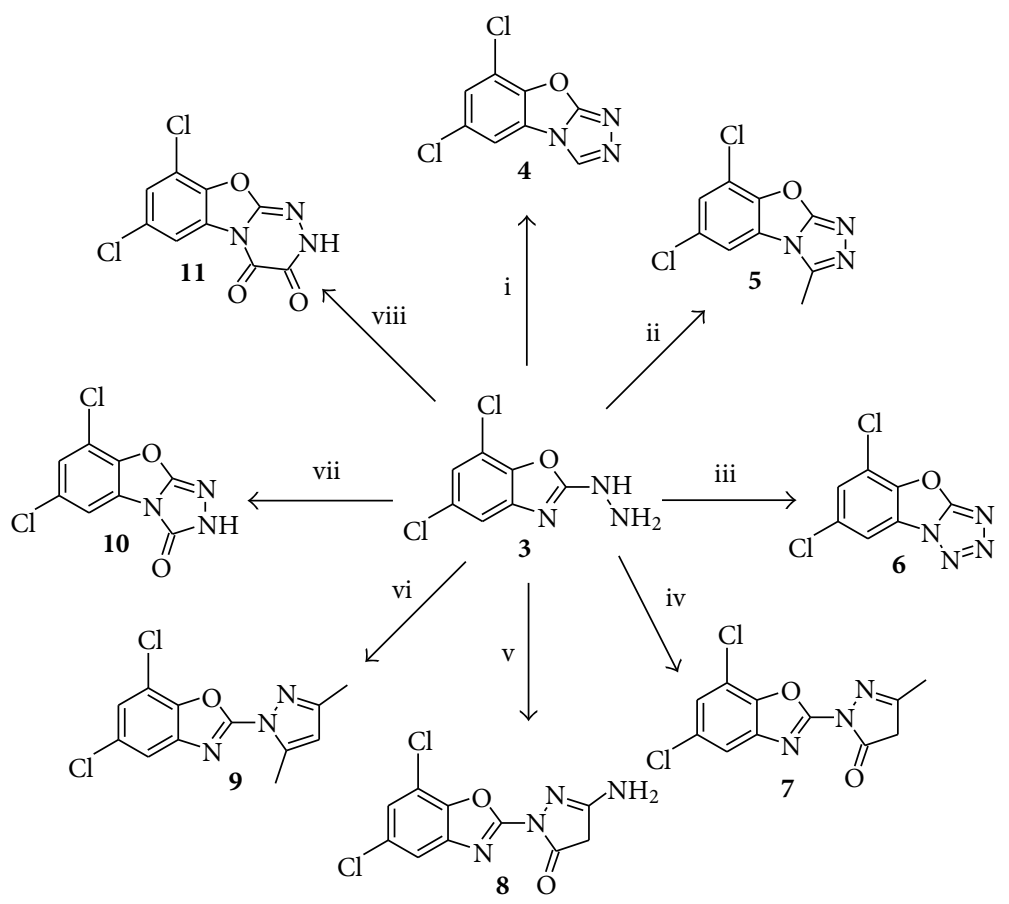

Scheme 2: Synthesis of compounds 4-11. i: $\mathrm{HCOOH}$, ii: $\mathrm{CH}_{3} \mathrm{COOH}$, iii: $\mathrm{NaNO}_{2} / \mathrm{AcOH}$, iv: $\mathrm{CH}_{3} \mathrm{COCH}_{2} \mathrm{COOC}_{2} \mathrm{H}_{5}, \mathrm{v}: \mathrm{CNCH}_{2} \mathrm{COOC}_{2} \mathrm{H}_{5}$, vi: $\mathrm{CH}_{3} \mathrm{COCH}_{2} \mathrm{COCH}_{3}$, vii: $\mathrm{ClCOOC}_{2} \mathrm{H}_{5}$, viii: $\left(\mathrm{COOC}_{2} \mathrm{H}_{5}\right)_{2}$.

for six protons at $\delta 3.0-3.04$ confirmed the formation of compound 9. The compound 3 was cyclized with ethyl chloroformate and with diethyl oxalate furnished 6,8dichloro[1,2,4] triazolo[3,4- $b][1,3]$ benzoxazol-3(2H)-one 10 and 7,9-dichloro- $2 H$ - $[1,2,4]$ triazine $[3,4-b][1,3]$ benzoxazole3,4-dione $\mathbf{1 1}$, respectively.

3.2. Biological Evaluation. The results of antibacterial activity of compounds 4-11 were shown in Table 2. In the antibacterial study, the compounds have shown inhibition of test bacteria. Among synthesized compounds, marked inhibition of test bacteria was observed to compounds 4,5 , and 8 , while least activity was observed to compounds 7 and 9 .

Minimum inhibitory concentration of synthesized compounds against test bacteria ranged from $250 \mu \mathrm{g} / \mathrm{mL}$ to $7500 \mu \mathrm{g} / \mathrm{mL}$. The compounds $\mathbf{4}, \mathbf{5}$, and $\mathbf{8}$ caused high inhibition at low concentration and are reported in Table 3.
Figure 1 explains antioxidant activity at different concentrations of compounds 4-11 in methanol and ascorbic acid in terms of free radical scavenging ability which was evaluated using DPPH free radical assay. The compounds exhibited marked antioxidant activity by scavenging $\mathrm{DPPH}^{*}$ (free radical) and converting into $\mathrm{DPPH}$, and the activity was found to be dose dependent. The compound 5 was shown to be more potent than ascorbic acid, and results were tabulated in Table 4.

The result of reducing power at different concentrations of compounds 4-11 and tannic acid is represented in Table 5. In this study, the absorbance was found to be increased with the dose of compounds and standard, which is suggestive reducing power (Figure 2). The compounds 4, 6, 7, and 11 showed remarkable reducing power.

Inhibitory activity on chicken pancreatic lipase at different concentrations of compounds in DMSO was determined using olive oil as the substrate. It was found that, the activity 
TABLE 2: Antibacterial activity of compounds 4-11.

\begin{tabular}{|c|c|c|c|c|c|}
\hline \multirow{2}{*}{ Compounds } & \multicolumn{5}{|c|}{ Zone of inhibition of test bacteria (in $\mathrm{cm}$ ) } \\
\hline & B. cereus & S. aureus & P. aeruginosa & K. pneumoniae & E. coli \\
\hline 4 & 2.8 & 1.9 & 2.3 & 2.6 & 2.1 \\
\hline 5 & 2.4 & 2.5 & 2.2 & 2.6 & 2.2 \\
\hline 6 & 2.4 & 2.0 & 1.3 & 1.6 & 1.3 \\
\hline 7 & 1.3 & 1.4 & 1.4 & 1.8 & 1.8 \\
\hline 8 & 3.0 & 2.1 & 2.2 & 2.4 & 2.6 \\
\hline 9 & 1.0 & 0.8 & 0.8 & 1.1 & 0.8 \\
\hline 10 & 1.8 & 2.0 & 1.5 & 1.9 & 1.8 \\
\hline 11 & 1.9 & 1.6 & 1.7 & 1.8 & 1.8 \\
\hline DMSO & 0.0 & 0.0 & 0.0 & 0.0 & 0.0 \\
\hline Standard & 3.1 & 3.0 & 2.8 & 2.7 & 2.8 \\
\hline
\end{tabular}

Standard-Chloramphenicol.

TABLE 3: MIC of compounds 4-11.

\begin{tabular}{|c|c|c|c|c|c|}
\hline \multirow{2}{*}{ Compounds } & \multicolumn{5}{|c|}{$\mathrm{MIC}$ in $\mu \mathrm{g} / \mathrm{mL}$} \\
\hline & B. cereus & S. aureus & P. aeruginosa & K. pneumoniae & E. coli \\
\hline 4 & 250 & 750 & 500 & 500 & 750 \\
\hline 5 & 500 & 500 & 750 & 500 & 750 \\
\hline 6 & 500 & 1000 & 2000 & 1500 & 2000 \\
\hline 7 & 2000 & 2000 & 2000 & 1500 & 1500 \\
\hline 8 & 250 & 750 & 750 & 500 & 500 \\
\hline 9 & 5000 & 7500 & 7500 & 1000 & 7500 \\
\hline 10 & 750 & 750 & 1000 & 750 & 750 \\
\hline 11 & 750 & 1000 & 750 & 750 & 750 \\
\hline DMSO & 0.0 & 0.0 & 0.0 & 0.0 & 0.0 \\
\hline Standard & 250 & 250 & 250 & 250 & 250 \\
\hline
\end{tabular}

Standard-Chloramphenicol.

TABLE 4: DPPH radical scavenging activity of compounds 4-11.

\begin{tabular}{lccccc}
\hline \multirow{2}{*}{ Compounds } & \multicolumn{5}{c}{$\begin{array}{l}\text { DPPH radical scavenging activity (\%) of different } \\
\text { concentrations }\end{array}$} \\
& 400 & 200 & 100 & 50 & 25 \\
\hline $\mathbf{4}$ & 85.71 & 73.01 & 68.25 & 60.32 & 53.96 \\
$\mathbf{5}$ & 97.56 & 95.12 & 93.90 & 92.68 & 91.46 \\
$\mathbf{6}$ & 73.01 & 57.14 & 55.55 & 53.96 & 47.62 \\
$\mathbf{7}$ & 95.24 & 93.65 & 93.65 & 92.06 & 90.47 \\
$\mathbf{8}$ & 96.82 & 95.04 & 93.05 & 87.30 & 85.71 \\
$\mathbf{9}$ & 90.47 & 85.71 & 73.01 & 60.32 & 53.96 \\
$\mathbf{1 0}$ & 92.68 & 87.80 & 71.95 & 67.07 & 64.63 \\
$\mathbf{1 1}$ & 93.65 & 90.47 & 88.89 & 76.19 & 71.42 \\
Standard & 97.33 & 95.12 & 93.14 & 90.33 & 86.69 \\
\hline
\end{tabular}

Standard-acetic acid.

of lipase was affected when incubated with the compounds. The inhibitory activity was found to be dose dependent that is, higher inhibition of enzyme was observed on increasing the concentrations of compounds (Figure 3). Lipase inhibition was more in case of compound $\mathbf{1 1}$. The results are tabulated in Table 6.
TABLE 5: Ferric reducing activity of compounds 4-11.

\begin{tabular}{lccccc}
\hline \multirow{2}{*}{ Compounds } & \multicolumn{5}{c}{ Ferric reducing activity of different } \\
& \multicolumn{2}{c}{ concentrations $(\mu \mathrm{g} / \mathrm{mL})$ of compounds } & $\mathbf{4}-1 \mathbf{1}(\%)$ \\
& 25 & 50 & 100 & 200 & 400 \\
\hline $\mathbf{4}$ & 0.43 & 0.53 & 0.55 & 0.59 & 0.66 \\
$\mathbf{5}$ & 0.45 & 0.48 & 0.51 & 0.55 & 0.61 \\
$\mathbf{6}$ & 0.49 & 0.51 & 0.55 & 0.61 & 0.68 \\
$\mathbf{7}$ & 0.51 & 0.54 & 0.65 & 0.68 & 0.73 \\
$\mathbf{8}$ & 0.41 & 0.44 & 0.49 & 0.51 & 0.54 \\
$\mathbf{9}$ & 0.41 & 0.47 & 0.52 & 0.55 & 0.59 \\
$\mathbf{1 0}$ & 0.46 & 0.50 & 0.53 & 0.56 & 0.62 \\
$\mathbf{1 1}$ & 0.53 & 0.58 & 0.61 & 0.66 & 0.71 \\
Tannic acid & 0.90 & 0.76 & 0.73 & 0.69 & 0.61 \\
\hline
\end{tabular}

The degree of lethality was found to be directly proportional to the concentration of the compounds. The highest mortality was observed at $1000 \mu \mathrm{g} / \mathrm{mL}$ concentration of compounds. The most potent activity was observed in case of compounds $\mathbf{6}$ and 8, whereas the mortality was $100 \%$ at the lowest concentration of compounds (Figure 4). LC 50 
TABLE 6: Pancreatic lipase inhibitory activity of compounds 4-11.

\begin{tabular}{lccccc}
\hline \multirow{2}{*}{$\begin{array}{l}\text { Compounds } \\
\end{array}$} & \multicolumn{5}{c}{ Inhibition of lipase activity (\%) } \\
\hline $\mathbf{4}$ & 35.19 & 20.07 & 10.00 & 06.55 & 0.0 \\
$\mathbf{5}$ & 39.84 & 30.54 & 20.46 & 09.44 & 0.0 \\
$\mathbf{6}$ & 37.90 & 22.79 & 21.55 & 10.95 & 0.0 \\
$\mathbf{7}$ & 50.69 & 35.96 & 23.30 & 12.01 & 0.0 \\
$\mathbf{8}$ & 57.28 & 42.94 & 29.05 & 14.34 & 0.0 \\
$\mathbf{9}$ & 59.80 & 38.68 & 27.82 & 15.42 & 0.0 \\
$\mathbf{1 0}$ & 59.80 & 41.39 & 25.50 & 16.45 & 0.0 \\
$\mathbf{1 1}$ & 72.86 & 54.94 & 40.67 & 19.77 & 0.0 \\
Standard & 96.61 & 94.30 & 93.12 & 89.21 & 0.0 \\
\hline
\end{tabular}

Standard-Orlistat.

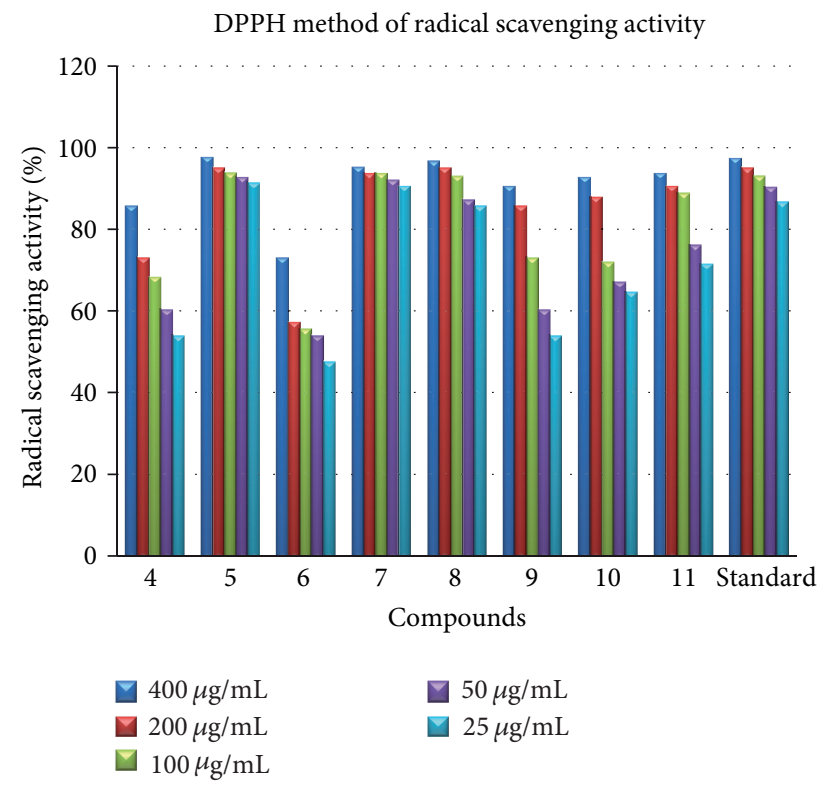

FIGURE 1: DPPH radical scavenging activity of compounds 4-11.

of compound 5, 10, and $\mathbf{1 1}$ was found to be 896.05, 22.85, and $31.99 \mu \mathrm{g} / \mathrm{mL}$, respectively, and the $\mathrm{LC}_{50}$ values were determined by linear regression using Origin 6.0 software.

The results are mentioned in Table 7.

\section{Conclusion}

This study reports the successful synthesis of the title compounds via different routes in good yield. The target molecules were characterized and confirmed by ${ }^{1} \mathrm{H}$ NMR, IR, Mass, and ${ }^{13} \mathrm{C}$ NMR spectral analysis and screened for selected biological activities. The compounds 4, 5, and 8 showed marked antibacterial activity, and compounds $\mathbf{1 0}$ and 11 exhibited potent pancreas lipase inhibitors, whereas compound $\mathbf{5}$ acted as scavengers and reducing agents. The compounds $\mathbf{6}$ and $\mathbf{8}$ showed potent cytotoxic activity. So, the derivatives of 5,7-dichloro-2-hydrazino-1,3-benzoxazole 3 were found to be biologically potent-fused heterocycles.

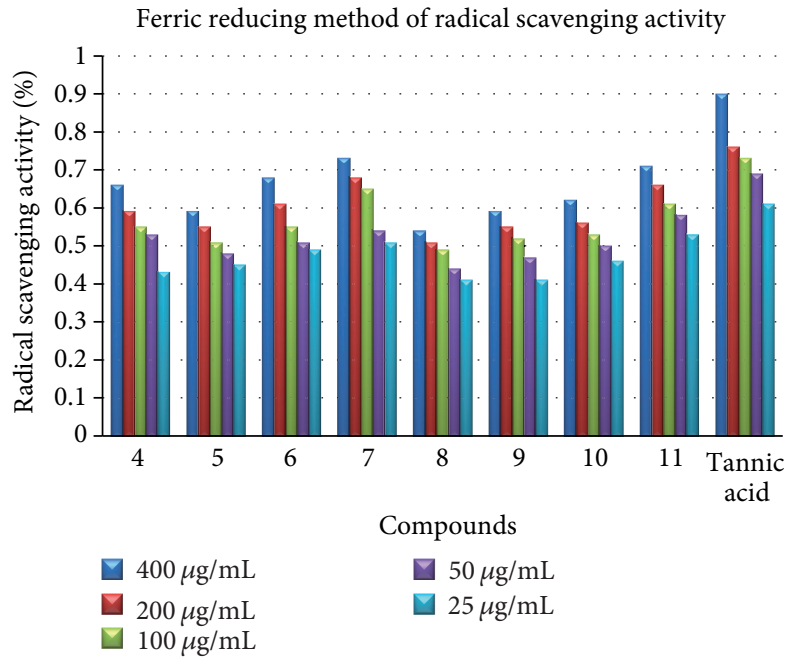

FIGURE 2: Ferric reducing activity of compounds 4-11.

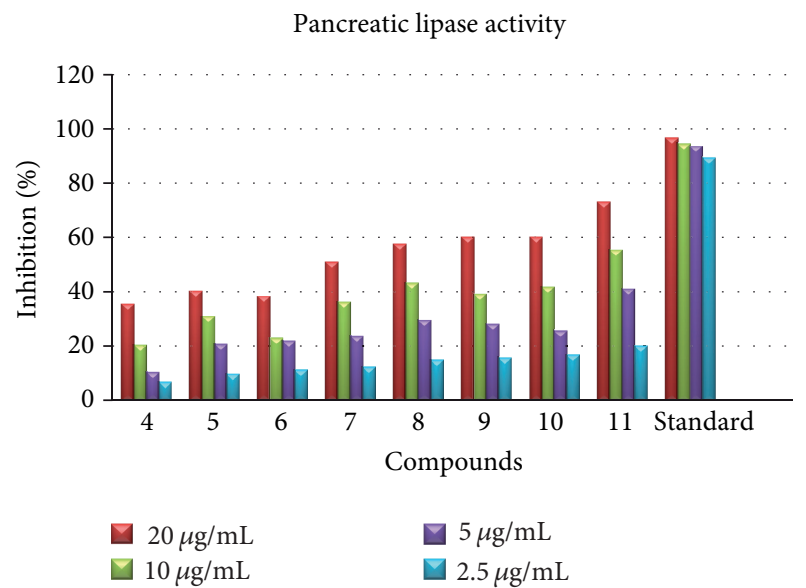

FIGURE 3: Pancreatic lipase inhibitory activity of compounds 4-11.

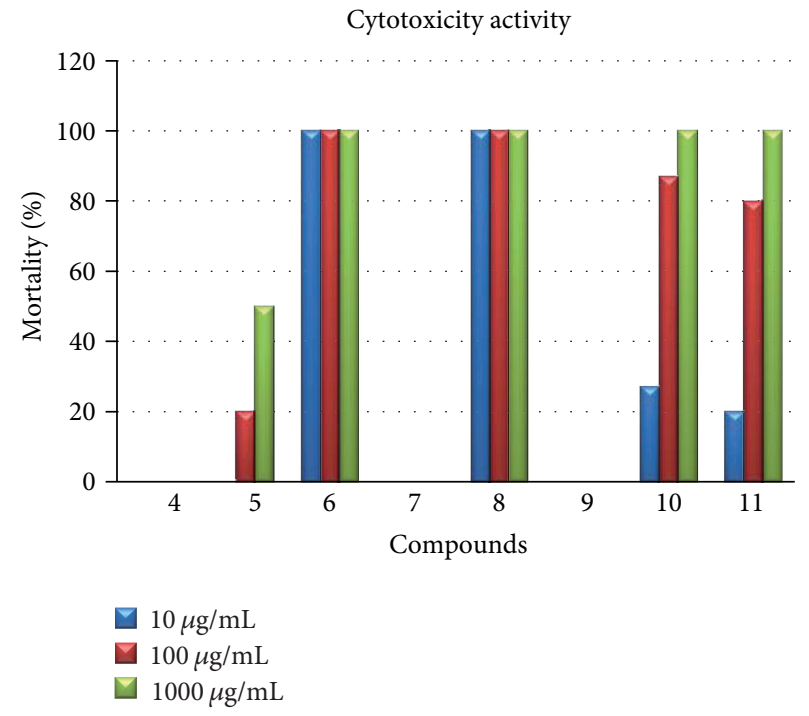

FIgURE 4: Cytotoxic activity of compounds 4-11. 
TABLE 7: Cytotoxic activity of compounds 4-11.

\begin{tabular}{lccc}
\hline Compounds & \multicolumn{3}{c}{ \% Mortality of Shrimps at } \\
& 10 & 100 & 1000 \\
\hline $\mathbf{4}$ & 0.0 & 0.0 & 0.0 \\
$\mathbf{5}$ & 0.0 & 20.0 & 50.0 \\
$\mathbf{6}$ & 100.0 & 100.0 & 100.0 \\
$\mathbf{7}$ & 0.0 & 0.0 & 0.0 \\
$\mathbf{8}$ & 100.0 & 100.0 & 100.0 \\
$\mathbf{9}$ & 0.0 & 0.0 & 0.0 \\
$\mathbf{1 0}$ & 27.0 & 87.0 & 100.0 \\
$\mathbf{1 1}$ & 20.0 & 80.0 & 100.0 \\
\hline
\end{tabular}

\section{Acknowledgments}

One of the authors (N. D. Jayanna) is grateful to UGC for providing Rajiv Gandhi Research Fellowship. The authors are thankful to the Director of IISc, Bangalore for providing spectral data and thankful to the Principal of Sahyadri Science College, Shimoga for providing laboratory facilities to carry out research work.

\section{References}

[1] P. K. Jauhari, A. Bhavani, S. Varalwar, K. Singhal, and P. Raj, "Synthesis of some novel 2-substituted benzoxazoles as anticancer, antifungal, and antimicrobial agents," Medicinal Chemistry Research, vol. 17, no. 2-7, pp. 412-424, 2008.

[2] S. M. Rida, F. A. Ashour, S. A. M. El-Hawash, M. M. ElSemary, M. H. Badr, and M. A. Shalaby, "Synthesis of some novel benzoxazole derivatives as anticancer, anti-HIV-1 and antimicrobial agents," European Journal of Medicinal Chemistry, vol. 40, no. 9, pp. 949-959, 2005.

[3] N. P. Bel'Skaya, M. A. Demina, S. G. Sapognikova et al., "Synthesis and oxidative cyclization of 2-arylhydrazono2-cyanoacetamidines to 5-amino-2-aryl-2H-[1,2,3] triazole-4carbonitrile," Arkivoc, vol. 2008, no. 16, pp. 9-21, 2008.

[4] A. T. Bijev and P. Prodanova, "Derivatives of 4-amino-4H-1,2,4triazole-3-thiols linked to the pyrrole cycle and some products of their S-alkylation," Chemistry of Heterocyclic Compounds, vol. 43, no. 3, pp. 306-313, 2007.

[5] A. Mohammed, K. Harish, and A. J. Sadique, "Synthesis and pharmacological evaluation of condensed heterocyclic 6substituted-1,2,4-triazolo[3,4-b]-1,3,4-thiadiazole derivatives of naproxen," Bioorganic and Medicinal Chemistry Letters, vol. 17, no. 16, pp. 4504-4508, 2007.

[6] V. Mathew, J. Keshavayya, and V. P. Vaidya, "Heterocyclic system containing bridgehead nitrogen atom: synthesis and pharmacological activities of some substituted 1,2,4-triazolo[3,4-b]1,3,4-thiadiazoles," European Journal of Medicinal Chemistry, vol. 41, no. 9, pp. 1048-1058, 2006.

[7] S. Nasser and A. M. Khalil, "N- and S- $\alpha$-l-Arabinopyranosyl[1,2,4] triazolo[3,4-b][1,3,4]thiadiazoles. First synthesis and biological evaluation," European Journal of Medicinal Chemistry, vol. 42, no. 9, pp. 1193-1199, 2007.

[8] P. Karegoudar, D. J. Prasad, M. Ashok, M. Mahalinga, B. Poojary, and B. S. Holla, "Synthesis, antimicrobial and anti-inflammatory activities of some 1,2,4-triazolo $[1,3,4]$ thiadiazoles and 1,2,4-triazolo[3,4-b]thiadiazines bearing trichlorophenyl moiety," European Journal of Medicinal Chemistry, vol. 43, no. 4, pp. 808-815, 2008.

[9] A. A. El-Barbary, A. Z. Abou-El-Ezz, A. A. Abdel-Kader, M. El-Daly, and C. Nielsen, "Synthesis of some new 4-amino1,2,4-triazole derivatives as potential anti-HIV and anti-HBV," Phosphorus, Sulfur and Silicon and the Related Elements, vol. 179, no. 8, pp. 1497-1508, 2004.

[10] H. S. El-Kashef, T. I. El-Emary, M. Gasquet, P. Timon-David, J. Maldonado, and P. Vanelle, "New pyrazolo[3,4-b]pyrazines: synthesis and biological activity," Pharmazie, vol. 55, no. 8, pp. 572-576, 2000.

[11] M. L. Taha, O. Moukha-Chafiq, H. B. Lazrek, J. J. Vasseur, and J. L. Imbach, "Synthesis of some acyclonucleosides $\alpha$ (pyrazolo[3,4-d]pyrimidin-4-ylthio)-alkylamides," Nucleosides, Nucleotides and Nucleic Acids, vol. 20, no. 4-7, pp. 955-958, 2001.

[12] C. B. Vicentini, G. Forlani, M. Manfrini, C. Romagnoli, and D. Mares, "Development of new fungicides against Magnaporthe grisea: synthesis and biological activity of pyrazolo[3,4$d][1,3]$ thiazine, pyrazolo[1,5-c] $[1,3,5]$ thiadiazine, and pyrazolo[3,4-d]pyrimidine derivatives," Journal of Agricultural and Food Chemistry, vol. 50, no. 17, pp. 4839-4845, 2002.

[13] Z. Brzozowski and F. Saczawski, "Synthesis and antitumor activity of novel 2-amino-4-(3,5,5-trimethyl-2-pyrazolino)1,3,5-triazine derivatives," European Journal of Medicinal Chemistry, vol. 37, no. 9, pp. 709-720, 2002.

[14] L. B. Hough, J. W. Nalwalk, R. Stadel et al., "Inhibition of improgan antinociception by the cannabinoid (CB)1, antagonist N-(piperidin-1-yl)-5-(4-chlorophenyl)-1-(2,4dichlorophenyl)-4-methyl-1 $H$-pyrazole-3-carboxamide (SR141716A): lack of obligatory role for endocannabinoids acting at CB1 receptors," Journal of Pharmacology and Experimental Therapeutics, vol. 303, no. 1, pp. 314-322, 2002.

[15] J. C. Jung, E. Blake Watkins, and M. A. Avery, "Synthesis and cyclization reaction of pyrazolin-5-one derivatives," Heterocycles, vol. 65, no. 1, pp. 77-94, 2005.

[16] E. Palaska, M. Aytemir, I. T. Uzbay, and D. Erol, "Synthesis and antidepressant activities of some 3,5-diphenyl-2-pyrazolines," European Journal of Medicinal Chemistry, vol. 36, no. 6, pp. 539-543, 2001.

[17] E. Bansal, V. K. Srivastava, and A. Kumar, "Synthesis and anti-inflammatory activity of 1 -acetyl-5-substitute daryl-3- $(\beta$ aminonaphthyl)-2-pyrazolines and $\beta$-(substitute daminoethyl) amidonaphthalenes," European Journal of Medicinal Chemistry, vol. 36, no. 1, pp. 81-92, 2001.

[18] J. H. Ahn, H. M. Kim, S. H. Jung et al., "Synthesis and DPIV inhibition of cyano-pyrazoline derivatives as potent antidiabetic agents," Bioorganic and Medicinal Chemistry Letters, vol. 14, no. 17, pp. 4461-4465, 2004.

[19] B. Tepe, E. Donmez, M. Unlu et al., "Antimicrobial and antioxidative activities of the essential oils and methanol extracts of Salvia cryptantha (Montbret et Aucher ex Benth.) and Salvia multicaulis (Vahl)," Food Chemistry, vol. 84, no. 4, pp. 519-525, 2004.

[20] F. Hasan, A. A. Shah, and A. Hameed, "Methods for detection and characterization of lipases: a comprehensive review," Biotechnology Advances, vol. 27, no. 6, pp. 782-798, 2009.

[21] Y. S. Ravikumar, K. M. Mahadevan, M. N. Kumaraswamy et al., "Antioxidant, cytotoxic and genotoxic evaluation of alcoholic 
extract of Polyalthia cerasoides (Roxb.) Bedd," Environmental Toxicology and Pharmacology, vol. 26, no. 2, pp. 142-146, 2008.

[22] M. Oyaizu, "Studies on product of browning reaction prepared from glucose amine," Japanese Journal of Nutrition, vol. 44, pp. 307-315, 1986.

[23] K. M. Shahani, I. M. Khan, and R. C. Chandan, "Bovine pancreatic lipase.I.Isolation, homogeneity, and characterization.", Journal of dairy science, vol. 59, no. 3, pp. 369-375, 1976.

[24] F. Hasan, A. A. Shah, and A. Hameed, "Methods for detection and characterization of lipases: a comprehensive review," Biotechnology Advances, vol. 27, no. 6, pp. 782-798, 2009.

[25] K. Werasit and A. Boonpan, "Screening of halophilic lipaseproducing bacteria and characterization of enzyme for fish sauce quality improvement," Kasetsart Journal, vol. 41, no. 3, pp. 576-585, 2007.

[26] A. H. S. Kumar, P. T. R. Kekuda, K. S. Vinayaka, D. Swathi, and T. M. Venugopal, "Anti-obesity (Pancreatic lipase inhibitory) activity of Everniastrum cirrhatum (Fr.) Hale (Parmeliaceae)," Pharmacognosy Journal, vol. 3, no. 19, pp. 65-68, 2011.

[27] J. L. McLaughlin, "Methods in plant biochemistry," in Assay For Bioactivity, K. Hostettmann, Ed., vol. 6, pp. 1-32, Academic press, London, UK, 1991.

[28] R. V. Satyendra, K. A. Vishnumurthy, H. M. Vagdevi, K. P. Rajesh, H. Manjunatha, and A. Shruthi, "Synthesis, in vitro antioxidant, anthelmintic and molecular docking studies of novel dichloro substituted benzoxazole-triazolo-thione derivatives," European Journal of Medicinal Chemistry, vol. 46, no. 7, pp. 3078-3084, 2011. 

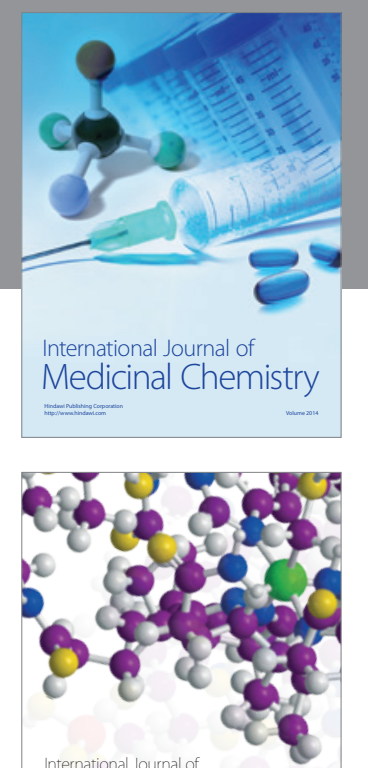

\section{Carbohydrate} Chemistry

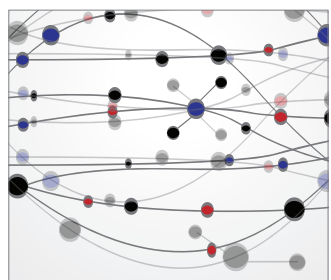

The Scientific World Journal
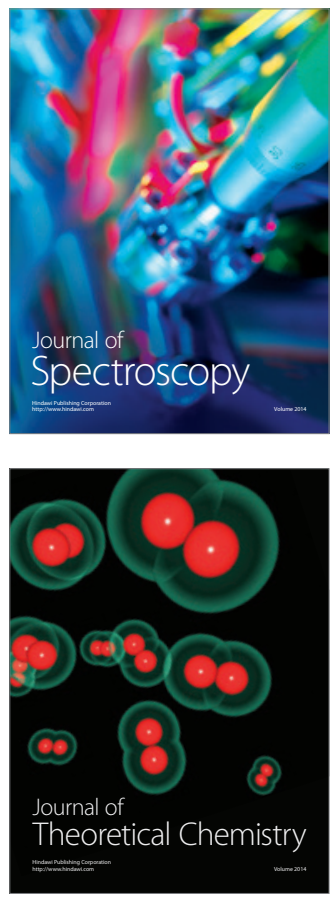
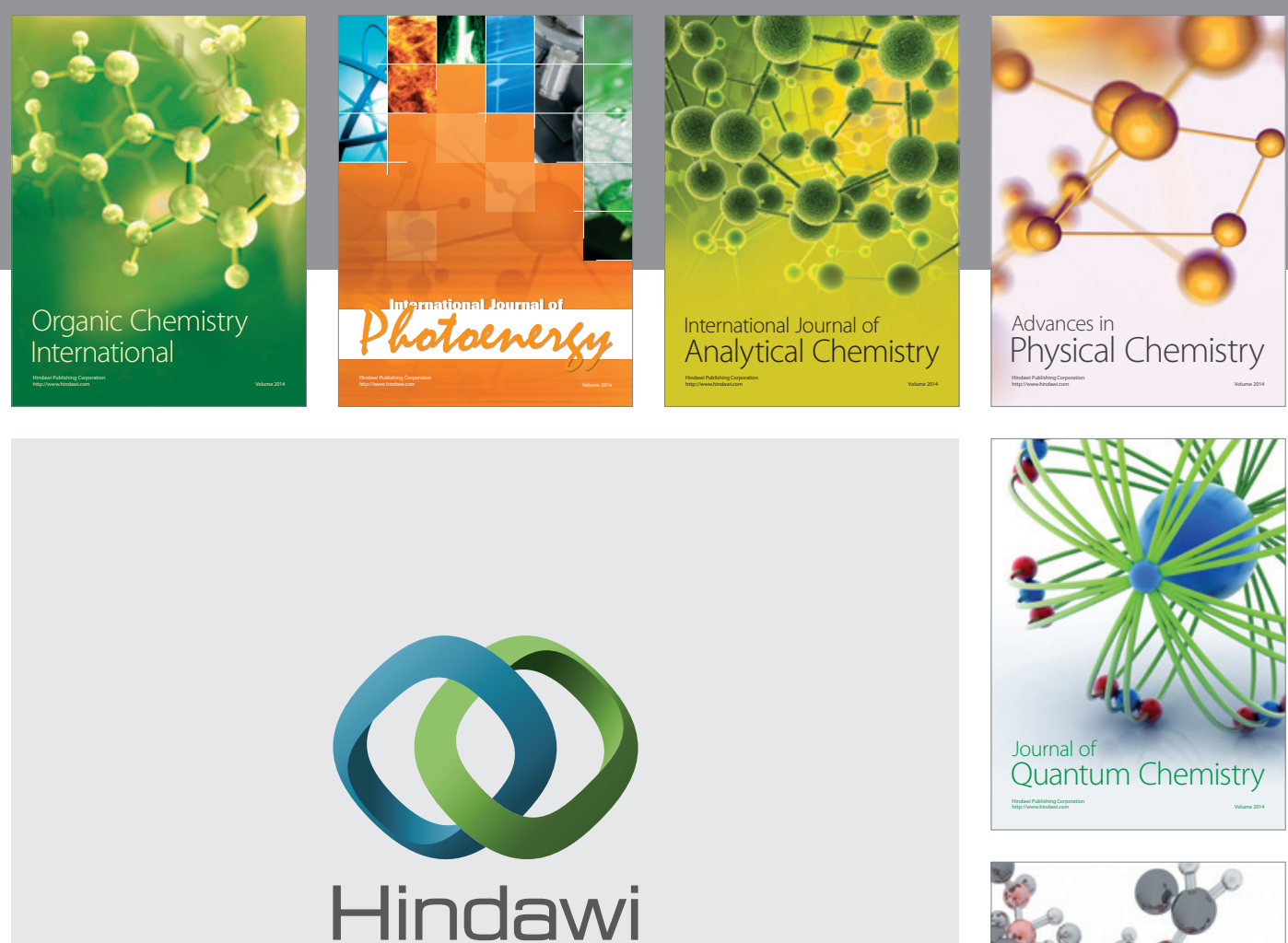

Submit your manuscripts at

http://www.hindawi.com

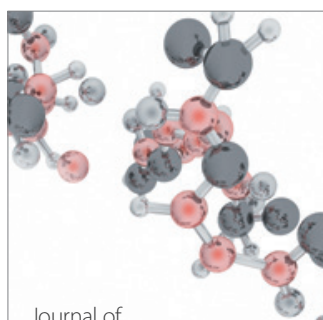

Analytical Methods

in Chemistry

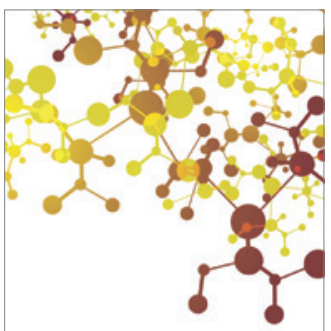

Journal of

Applied Chemistry

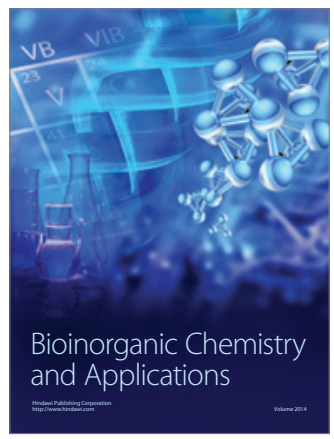

Inorganic Chemistry
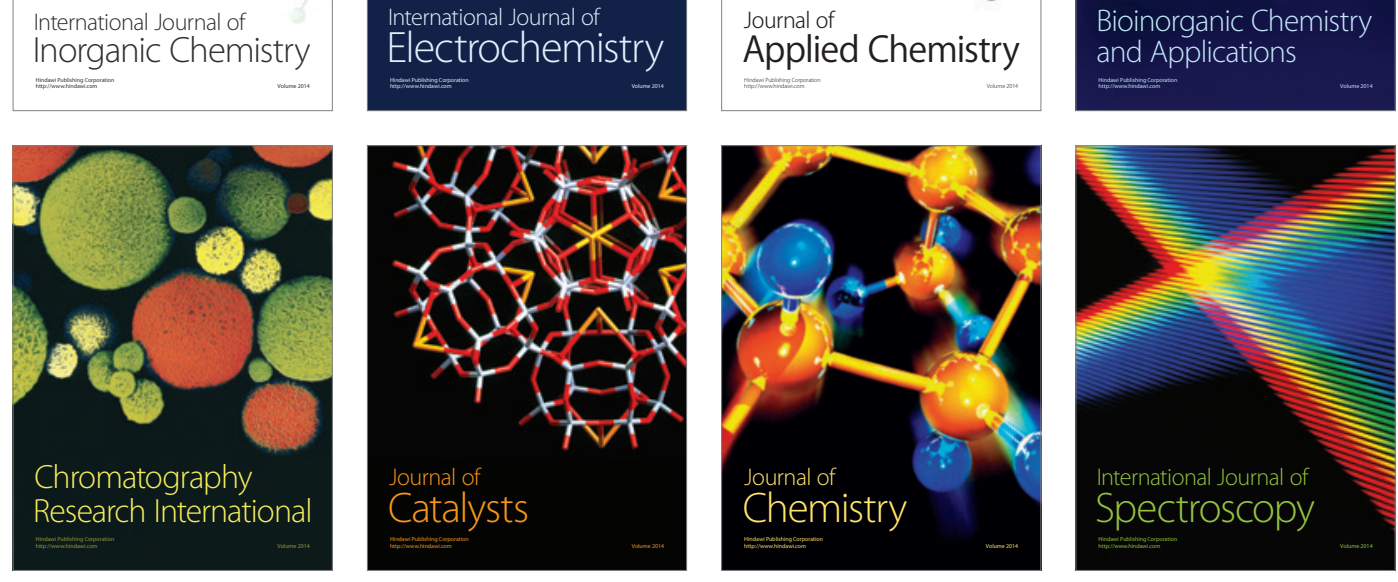